\title{
The influence of vibroacoustic therapy on the functional status of patients with gonarthrosis. A preliminary report
}

\author{
Wptyw terapii wibroakustycznej na stan funkcjonalny osób z gonartrozą. \\ Doniesienie wstępne
}

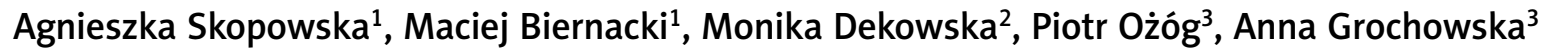 \\ ${ }^{1}$ Institute and Faculty of Laser Therapy and Physiotherapy, Collegium Medicum in Bydgoszcz, Nicolaus Copernicus in Toruń \\ 2Institute of Psychology, Kazimierz Wielki University in Bydgoszcz \\ 3“Physical Medicine" Student's Scientific Circle, Institute and Faculty of Laser Therapy and Physiotherapy
}

Key words: gonarthrosis, vibroacoustic therapy, functional status, VAS, TUG test.

Słowa kluczowe: gonartroza, terapia wibroakustyczna, stan funkcjonalny, skala VAS, test TUG.

\begin{abstract}
Sum mary
Aim of the study: Gonarthrosis is a degenerative disease of the articular cartilage. Its main symptoms are pain, swelling, stiffness, limitation of functions and deformations of the joint. One of the available methods of preservative treatment of gonarthrosis is vibroacoustic therapy (VT), which evokes micro-vibrations in the tissues - through the use of sound waves of variable frequency and amplitude. The aim of the study was to estimate the influence of $V T$ on the functional status of people with gonarthrosis.

Material and methods: Forty-four people, aged over 44, with gonarthrosis were subjected to 10 sessions of VT with the Vitafon- $T$ device, in a variable range of frequencies between 30 and $18000 \mathrm{~Hz}$. The sessions lasted 15 minutes. In order to estimate the effectiveness of the therapy, double measurements (before and after therapy) of the following parameters were taken: pain (VAS), joint circumferences and function tests (Timed Up and Go - TUG), the average free walking time at the $6 \mathrm{~m}$ distance and the knee bends test. The statistical analysis was carried out using the Wilcoxon test, with the significance level of $p<0.0001$.

Results: In the examined group a decrease was observed in: pain (by 1.9 VAS points among $77 \%$ of the patients), circumference of the joints among $91 \%$ and the time of conducting the TUG test in $96 \%$. The number of knee bends increased in $82 \%$ of the patients. All the results reached statistical significance $(p<0.0001)$. The free walking improved among 91\%; however, this result was not statistically significant.

Conclusions: Vibroacoustic therapy has brought positive treatment effects of an analgesic and anti-swelling character, which has further influenced the functional efficiency of the patients with gonarthrosis. The research still needs to be expanded to other groups of patients before the method may be popularized in primary care rehabilitation facilities.
\end{abstract}

\section{Streszczenie}

Cel pracy: Gonartroza jest chorobą, w której dochodzi do zaburzenia równowagi pomiędzy procesami regeneracji oraz degradacji chrząstki stawowej. Do jej głównych objawów należą: ból, obrzęk, sztywność, ograniczenie funkcji, a także deformacje stawu. Jedną z dostępnych, choć nowych, form leczenia zachowawczego gonartrozy jest terapia wibroakustyczna wywołująca w tkankach mikrowibracje - wykorzystująca fale dźwiękowe o zmiennej częstotliwości i amplitudzie. Celem badania była ocena wpływu terapii wibroakustycznej na stan funkcjonalny osób z gonartrozą.

Materiał i metody: Czterdzieści cztery osoby powyżej 44. roku życia z gonartrozą poddano 10 zabiegom terapii wibroakustycznej za pomocą aparatu Vitafon-T, w zmiennym przedziale częstotliwości 30$18000 \mathrm{~Hz}$. Zabiegi trwaty $15 \mathrm{~min}$. W celu oceny skuteczności terapii przed jej zastosowaniem i po jej zakończeniu dokonano pomiarów: bólu (skala VAS), obwodów stawów oraz testów czynnościowych (Time Up and Go - TUG), uśrednionego czasu chodu na dystansie $6 \mathrm{~m}$ oraz testu przysiadów. Analizę statystyczną wykonano za pomocą testu Wilcoxona, za poziom istotności przyjęto $p<0,0001$. Wyniki: W badanej grupie zaobserwowano zmniejszenie dolegliwości bólowych średnio o 1,9 pkt w skali VAS u 77\% badanych, obwodu leczonych stawów u 91\% osób oraz czasu wykonania testu TUG u 96\%. Liczba wykonanych przysiadów zwiększyła się u 82\% pacjentów. Wszystkie wyniki osiągnęły istotność statystyczną na poziomie $p<0,0001$. Chód swobodny poprawit się u 91\% badanych, wynik ten nie był jednak statystycznie istotny.

Wnioski: Terapia wibroakustyczna przyniosła pozytywne efekty lecznicze o charakterze przeciwbólowym i przeciwobrzękowym, co wpłynęło również na poprawę sprawności funkcjonalnej w grupie pacjentów z gonartrozą. Badania wymagają jednak rozszerzenia na inne grupy pacjentów o zróżnicowanej etiologii chorobowej, zanim upowszechni się jej stosowanie w ośrodkach rehabilitacyjnych podstawowej opieki zdrowotnej.

Address for correspondence:

Agnieszka Katarzyna Skopowska, MA, Institute and Faculty of Laser Therapy and Physiotherapy, Collegium Medicum in Bydgoszcz, Marii Skłodowskiej-Curie 9, 85-094 Bydgoszcz, tel. +48 52585 34 85, e-mail: amdg@o2.pl

Submitted: 18.11.2013 


\section{Introduction}

Osteoarthritis (OA) is characterised by progressive damage of the articular cartilage accompanied by its insufficient rebuilding and by inflammation of the soft tissues adjacent to the joint. During the course of the disease, increased activity of the enzymes degrading cartilage, i.e. interleukin 1 (IL-1), transforming growth factor (TGF) and metalloproteinases, occurs [1, 2]. The extenuation of the hyaline layer and the presence of inflammation in the synovial membrane leads to dysfunction of the affected and, eventually, the adjacent joints. The frequency of knee OA occurrence increases with age. Overweight and obesity contribute to its development. Degenerative changes in joints are recognized in every patient aged over $65[3,4]$.

Gonarthrosis most often afflicts obese women with hormonal imbalance; among men it is connected with work overload, physical effort or injuries. Moreover, anatomical anomalies such as a history of hip dysplasia, genu valgum or genu varum and surgical treatment seem to be frequent causes of the second form of OA. This pathosis causes a defect in the functionality of a knee joint in around $10 \%$ of people over 55 , among a quarter of whom it contributes to the development of a severe disability. In Poland, $25 \%$ of the 8 million cases of osteoarthritis concern knee joints $[3,5,6]$.

The disease is diagnosed on the basis of a clinical and imaging examination (magnetic resonance imaging [MRI], X-ray) as well as some additional examinations, i.e. bone scintigraphy and arthroscopy. Pain, the source of which is the periarticular tissues, depends on the position of the knee and the size of the load. In later stages of the disease, the pain also occurs at rest. According to the American College of Rheumatology (ACR), criteria for diagnosis of knee osteoarthritis include: strong pain, swelling, morning stiffness, joint space narrowing, the presence of osteophytes and popping during joint movements as well as subluxations or genu varum [3, 7].

The optimum treatment of OA should by carried out in a complex manner and requires a proper combination of pharmacological treatment and individually suited rehabilitation. Moreover, the factors that should be taken into consideration here are: age and accompanying diseases, the degree of the pain and disability, and the patient's personal expectations as to the treatment. Commonly recommended are physical exercises and physical therapies which prove effective in reducing the pain, have an antiphlogistic effect, relax the muscles and improve the patient's quality of life. The subsequent step is an improvement in movements, coordination and balance, resulting in a general enhancement of walking and limitation of the risk of falls [4, 8-10].
One of the less frequently applied methods of physical treatment is vibroacoustic therapy. The effect of the functioning of mechanical waves, which are sound waves produced by the Vitafon device, is to induce oscillation of the particles that form the environment in which they propagate in a certain range of frequencies, creating the microvibrations [11-13]. Alternate condensations and dilutions of the environment are the basis of biological effects the mechanical waves exert in a human body [14]. The aptness of applying vibroacoustic therapy is based on the fact that living creatures constantly use the energy of microvibrations at the cellular level. Microvibrations are created during various biological processes, such as the contraction of the muscle cells (movement, rest), vocal cord vibration (speaking), and the pulsation of the blood and lymphatic vessels [13]. It is acknowledged that these pulsations, similarly to heat in intermolecular interactions, are resources in short supply among all warm-blooded organisms. It is assumed that the work of muscles of the entire human body uses up around $80 \%$ of all energetic resources. After injury or too intense physical effort, in chronic tiredness resulting from stress, or in old age, an energetic deficiency may take place as well as a lack of microvibrations. The microvibrations are crucial in the process of retrieving energy and in immunologic reactions. Vibroacoustic devices are able to topically increase the energetic level to the optimum, which should lead to positive physiological changes, i.e. [13, 15]:

- more rapid disposal of metabolic products and inflammatory substances;

- an improvement in the microcirculation and transport of lymph and the nutrition of cells;

- support of the regeneration processes;

- reinforcement of interaction of cells within the immunological system;

- participation in transport of stem cells around the body. Owing to these properties, vibroacoustic therapy contributes to the reduction of swelling and pain in situ, improves the blood supply of the tissues, accelerates the reaction of the immunologic system and enhances the effectiveness of the pharmacological treatment. The results of some studies reveal that in the case of applying microvibrations at the level of the liver and kidneys, their functioning is improved and the pain of the lumbo-sacral part of the spine is reduced $[13,16,17]$.

Vibroacoustic therapy is based on the influence of microvibrations of variable acoustic frequencies (of the range between 0.1 and $18000 \mathrm{~Hz}$ ) with the amplitude of the vibrations up to a maximum of $50 \mu \mathrm{m}$ (0.0001-0.05 $\mathrm{mm}$ ) on human tissues. The advantage of this therapy is the simplicity of its application, the impact on the chemism of the tissues and the micromassage of struc- 
tures submitted to the treatment. Four therapeutic programmes are distinguished, which vary according to the different intensity of the doses. The length of the therapy ranges between 5 and 60 minutes, applied from one to three times a day. The vibroacoustic sessions using the Vitafon apparatus may be a magnificent preparation for healing exercises. It ought not to be applied in cancerous conditions, inflammation of the veins, pregnancy or kidney calculus $[11,13,18]$.

\section{Aim}

The aim of this preliminary study was to prove the effectiveness of vibroacoustic therapy as a monotherapy applied in patients with gonarthrosis.

\section{Material and methods}

A group of 44 patients (20 men and 24 women) suffering from degenerative knee joint disease participated in the study (the average age was 64.85). On the basis of an interview and the X-ray imaging, patients with a history of injuries and with recent inflammation of the knee joint area were excluded. The majority of the patients were diagnosed with knee joint osteoarthritis of the second stage, and only $7 \%$ of cases with the third stage. Half of the patients were overweight. Two of the

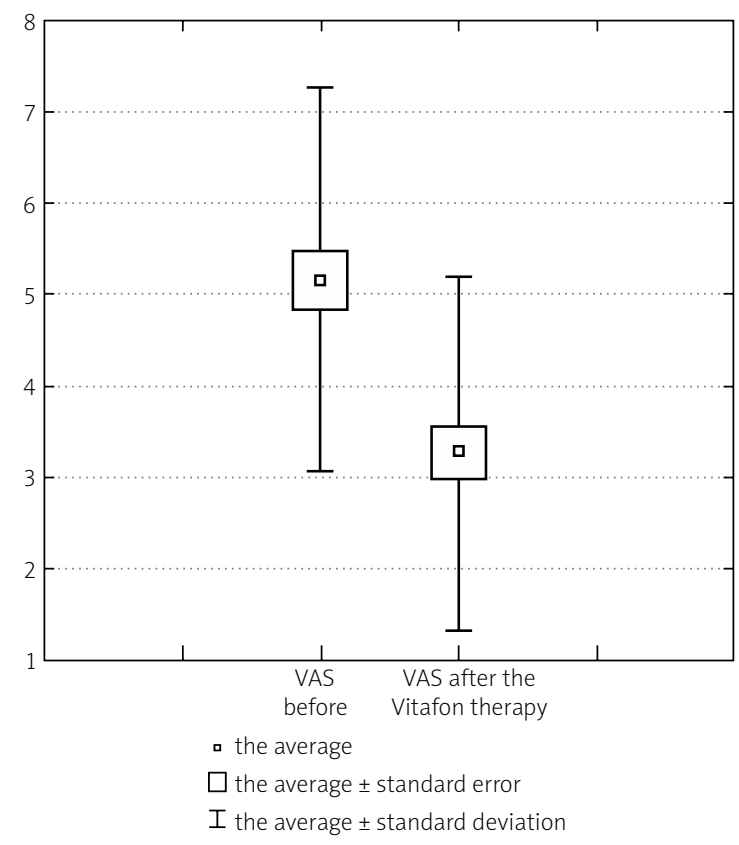

Fig. 1. Differences in the level of perceived pain (VAS) among patients with gonarthrosis, before and after applying vibroacoustic therapy $(n=44)$. The $Y$-axis indicates the VAS score $(0-10) ; p<0.0001$. patients moved using crutches; $70 \%$ of the participants were no longer professionally active, and 4 people in the entire group spent their time actively cycling or running.

A series of 10 sessions of vibroacoustic therapy was carried out. The Vitafon-T's present treatment programmes 1 and 4 (recommended by the producers) were applied in a periodically altered range of acoustic frequencies between 30 and $18000 \mathrm{~Hz}$. The length of each session was 15 minutes. The applicators, after being attached, adhered directly to the skin around the knee joints. The treatment procedure proposed by the producer was intentionally changed so that it was possible to perform in outpatient conditions among a broader group of patients.

To assess the effectiveness of the therapy, double measurements (before and after therapy) were conducted of: the level of the perceived pain on the day of the examination (VAS), the circumferences of the knee joints ( $5 \mathrm{~cm}$ above the joint space) and the functions of the lower limbs. The following functional tests were carried out:

- the mobility and the risk of fall assessment test "Timed Up and Go" (TUG);

- the average time of free walking over 6-metre distance test;

- the test of the number of knee bends done without experiencing discomfort and/or pain.

Twenty randomised patients were additionally asked about the frequency of taking painkillers and non-steroid anti-inflammatory drugs (NSAIDs). This group also assessed changes in pain intensity expressed in terms of the use of painkillers and an assessment of changes in mobility using a modified pain indicator questionnaire by Laitinen.

The consecutive arithmetic averages and standard deviations were calculated. To compare particular pairs of variables in a statistical analysis, the Wilcoxon test was used where the significance level was established at $\alpha=0.0001$. The Statistica 10 software was used in the calculations. The research conducted in 2011 was approved by the Bioethical Commission at the Collegium Medicum in Bydgoszcz.

\section{Results}

Prior to the vibroacoustic therapy, patients were asked about the subjective level of perceived pain on the VAS scale, which was $5.17(S D=2.1)$ on average. Once the therapy had been completed, after 14 days, a decrease in joint pain was observed, by 1.9 points in $77 \%$ of patients, down to the value of $3.27(S D=1.94)$ (Fig. 1). The reduction of pain was also connected with a reduction in the circumference of the sore knee joints (by $0.88 \mathrm{~cm}$ on average) in $91 \%$ of patients (Fig. 2). Be- 


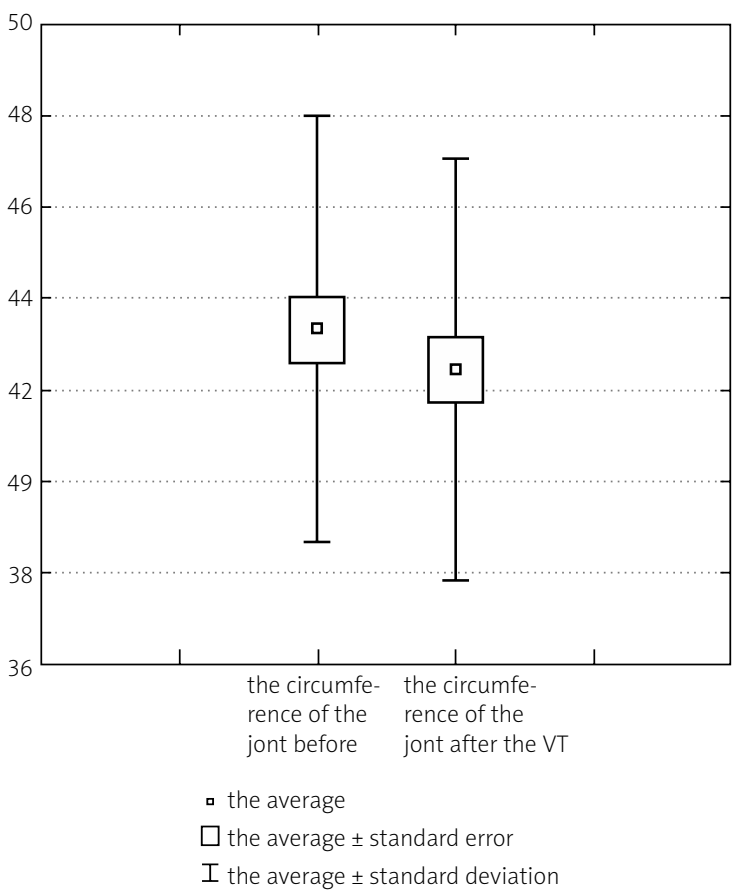

Fig. 2. Differences in the circumferences of the knee joints among patients with gonarthrosis, before and after applying the therapy with the Vitafon device $(n=44)$. The Y-axis indicates the treated joint circumference in $\mathrm{cm} ; p<0.0001$.

fore the treatment, the average value for the circumferences was $43.31 \mathrm{~cm}(S D=4.66)$ and after the sessions it decreased to $42.43 \mathrm{~cm}(S D=4.61)$.

There was also a slight improvement in the time of free walking over a 6-metre distance on a flat surface in 91\% of the examinees. The time of the TUG test performance decreased by 1.0 s, on average (Fig. 3), in $96 \%$ of patients, from the initial values of $M$ (mean) $=10.13 \mathrm{~s}$ $(S D=2.45)$ to $M=9.13 \mathrm{~s}(S D=2.17)$. The majority of patients noticed a decrease in constraints of physical activity and an increase in the smoothness of walking. The squat test revealed a rising tendency by 5 squats, on average, suggesting an improvement in the functionality (Fig. 4). Initially, among $38.5 \%$ of the patients, performing even a single squat was impossible $(M=2.13$, $S D=2.89$ ). After the therapy the number of painlessly performed squats significantly increased - in $82 \%$ of patients $(M=7.02, S D=5.2)$.

During the study, the patients with gonarthrosis started using NSAIDs less frequently and in smaller amounts (Fig. 5). In 20 randomly chosen patients in whom the Laitinen test was carried out it revealed a significant decrease in the frequency and intensity of pain related to OA. Before the vibroacoustic therapy, these values amounted to 5.8 points, on average $(S D=1.85)$ with the minimum level

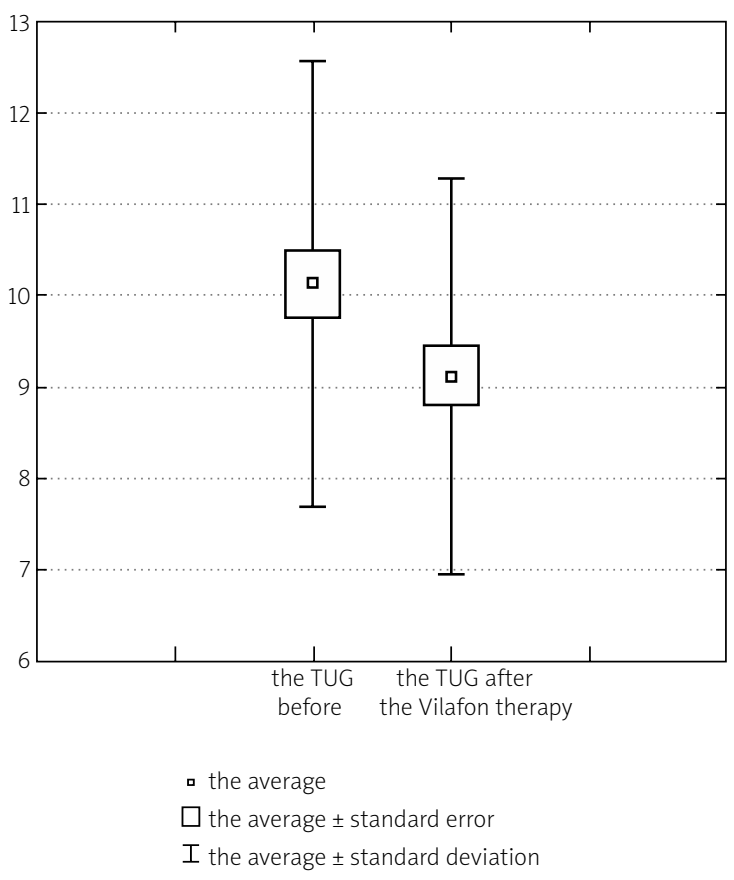

Fig. 3. Differences in the results of the TUG test among the patients with gonarthrosis, before and after vibroacoustic therapy $(n=44)$. The $Y$-axis indicates time of the TUG test in seconds; $p<0.0001$.

of 3.94. After the treatment, they decreased to a minimum of 1.22 with an average of $2.7(S D=1.45)$.

\section{Discussion}

There is a body of literature concerning application and effectiveness of vibroacoustic therapy $[12,15,16$, 19]. The research on its effectiveness reveals significant improvement of health condition in patients with inflammations of the joints and nerve roots or backaches. Cessation of the inflammatory process is also acknowledged among people suffering from bladder and nipple infection or prostate adenoma. Also a shortening of the time of healing of broken bones was observed in patients who used vibroacoustics as part of their rehabilitation programme [11, 13, 20, 21]. Worth emphasizing are two Polish studies by Łukasiak et al. [17] on the treatment of enthesopathy of the tuber calcanei and research by Stępień et al. [18] - on post-operative Dupuytren's contracture therapy.

Patients with cancerous conditions, inflammation of the veins, pregnancy or kidney calculus are excluded from the use of vibroacoustics. A number of patients may also be bothered by the extended length of the therapy - from 4 to 6 hours. The presented research, however, indicates that this period may be shortened. 


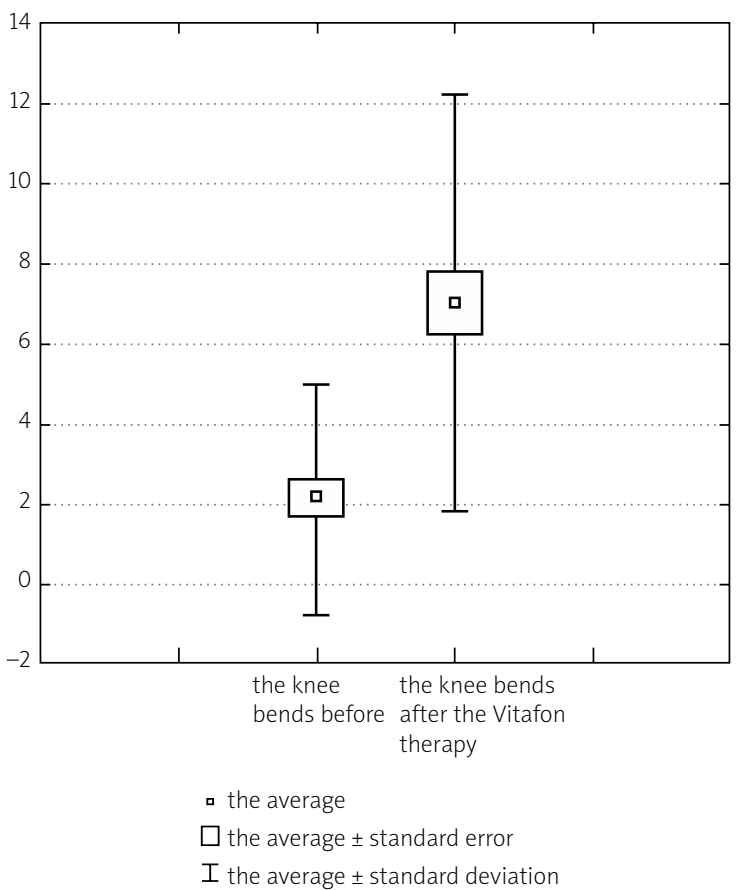

Fig. 4. Differences in the results of the squat test among the patients with gonarthrosis, before and after vibroacoustic therapy $(n=44)$. The $Y$-axis indicates the number of squats performed; $p<0.0001$.

In the first study [17], 60 patients with calcaneal spur were divided into two subgroups: I - submitted to vibroacoustic therapy, II - submitted to combined laser therapy and sonotherapy. In both groups, statistically significant and satisfactory remission of pain was observed; however, the decrease averaged 2.6 VAS points in the group applying Vitafon, in contrast to only 0.6 points in the laser sonotherapy group. A similar percentage of patients with decreased intensity of pain by 1.9 points, on average, and improved functionality were found in the hitherto presented research - in patients with gonarthrosis - after applying the $1^{\text {st }}$ and $4^{\text {th }}$ therapeutic programmes during 15-minute sessions. In the majority of patients, the mechanics of the movements and the quality of walking improved.

In the research carried out by Stępień et al. [18] in a group of 20 patients operated on due to Dupuytren's contracture in whom mechanical waves inter alia were applied, a 70\% decrease in pain was observed as well as an increase in the range of motion of the operated fingers joints. Both in the group where vibroacoustic waves monotherapy was used and the one where it was combined with laser therapy, a distinguishable improvement of the health condition of patients was observed. These results prove the high effectiveness of vibroacoustic

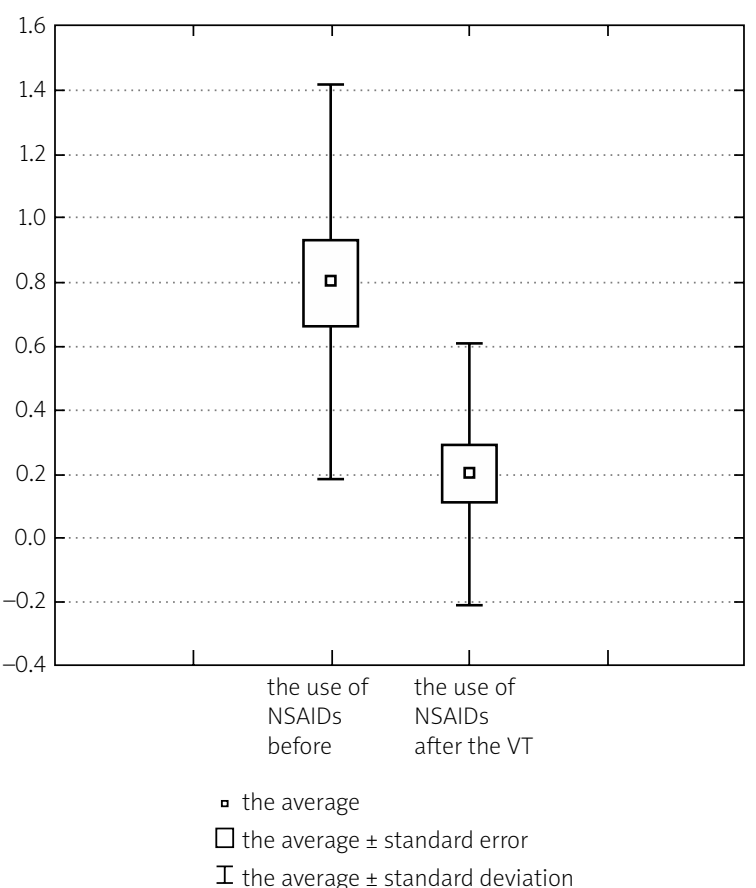

Fig. 5. Differences in the frequency of use of NSAIDs by the patients with gonarthrosis, before and after vibroacoustic therapy $(n=20)$. The $Y$-axis indicates the frequency of use of NSAIDs on the Laitinen scale (0-4); $p<0.01$.

therapy and the purposefulness of its combination with other forms of treatment in various diseases of the locomotor system.

The positive effects of the treatment with mechanical waves in the range of ultrasounds are reported by many research teams $[9,22]$. This concerns not only cases of gonarthrosis but also cases of coxarthrosis, enthesopathy, fibromyalgia, periarticular inflammation of the shoulder and carpal tunnel syndrome [23, 24]. This therapy is also commonly used in the field of sport medicine [25]. Together with NSAIDs in the form of a gel (phonophoresis in a dose of $0.4 \mathrm{~W} / \mathrm{cm}^{2}$ in a 5 -minute session plus $1 \%$ diclofenac), very good therapeutic results may be obtained in patients with first degree gonarthrosis [26]. Positive effects are reported concerning one type of sonotherapy - LIPUS (low-intensity pulsed ultrasound) with regards to various locomotor system diseases. The method is based on 20-minute sessions using low-intensity energy transmitted via impulses [27].

Many authors report the positive effects of other forms of physical therapy such as laser radiation, magnetic fields or thermotherapy, applied in patients with gonarthrosis [9, 28, 29]. Among the most effective methods are cryotherapy - for 3 minutes; laser therapy (usually as a contact method using a wavelength of $810 / 820$ 
$\mathrm{nm}$ in doses of 5 to $8 \mathrm{~J} / \mathrm{cm}^{3}$ ) and a low-frequency pulsed magnetic field (through the magnetic induction of about $7 \mathrm{mT}$, frequency of $20 \mathrm{~Hz}$ over 15 -minute sessions). After these therapies, in all studied groups of patients, considerable pain relief was observed as well as a decrease of joint swelling and improvement of walking in $75 \%$ of individuals. Also in the present study, with the use of a mechanical wave, a statistically significant decrease of joint swelling, better quality of walking, an analgesic effect, and improvement in functionality of the lower limbs - with regards to doing knee bends and walking on the steps - were observed in the majority of subjected patients.

Although a significant improvement of all above-mentioned parameters has been observed in our study, we are leaning toward extending and randomising the sample group. This is a pilot study, and therefore requires validation, which is associated with the presence of a control group. Currently, studies with ultrasound therapy are also being conducted in patients with OA. In the future, we would like to apply combined therapy, e.g. with laser therapy, cryotherapy or physiotherapy, due to their reported high effectiveness $[5,9,29]$. The increase in muscle strength, and improvement in body balance and coordination, will surely contribute to the prolongation of the therapeutic effects in patients with gonarthrosis.

\section{Conclusions}

Vibroacoustic therapy has brought positive healing effects of an analgesic and anti-swelling character among patients with gonarthrosis which, eventually, enhanced the general mobility.

Due to the positive effect of vibroacoustic therapy in patients with gonarthrosis, it may become one of the elements of the healing process of degenerative changes in the knee joints. The intentionally changed vibroacoustic therapy procedure, adapted to the National Health Fund treatment system, provides opportunities of application in a broader group of patients - which does not exclude the use of the producer's recommendations.

It is advisable to extend the sample group to other groups of patients with diverse disease aetiology, according to evidence-based medicine.

\section{The authors declare no conflict of interest.}

\section{References}

1. Hulejová H, Baresová V, Klézl Z, et al. Increased level of cytokines and matrix metalloproteinases in osteoarthritic subchondral bone. Cytokine 2007; 38: 151-156.

2. Dyndor P, Dyndor K, Maciejewski R, et al. Wspótczesne poglądy na temat roli i patogenezy choroby zwyrodnieniowej stawu kolanowego. Zdrowie Publiczne 2012; 122: 206-210.
3. Kwiatkowski K. Gonartroza - patomechanizm, występowanie i czynniki ryzyka. Chirurgia Kolana, Artroskopia, Traumatologia Sportowa 2004; 4: 75-88.

4. Ciejka E, Wojtowicz K. Ocena skuteczności stosowanych zabiegów fizjoterapeutycznych w leczeniu choroby zwyrodnieniowo-wytwórczej stawów obwodowych i kręgosłupa. Balneologia Polska 2009; 53: 189-193.

5. Łukowicz M, Szymańska J, Buszko K, et al. Terapia skojarzona łącząca laseroterapię i magnetoterapię jako metoda wspomagająca leczenie gonartrozy. In: Zdrowie - prawidłowe funkcjonowanie człowieka we wszystkich sferach życia. Kalisz Z, Hagner-Derengowska M, Żukow W (eds.). Bydgoszcz 2012: 139-146.

6. Piecuch R, Targońska-Stępniak B, Majdan M. Aktualne poglądy na leczenie choroby zwyrodnieniowej stawów. Lekarz 2008; 6: 81-88.

7. Bennell KL, Hinman RS, Metcalf BR, et al. Efficacy of physiotherapy management of knee joint osteoarthritis: a randomised, double blind, placebo controlled trial. Ann Rheum Dis 2005; 64: 906-912.

8. Zhang W, Moskowitz RW, Nuki G, et al. QARSI recommendations for the management of hip and knee osteoarthritis. Part II: QARSI evidence-based, export consensus quidelines. Osteoarthritis Cartilage 2008; 16: 137-162.

9. Łukowicz M, Weber-Rajek M, Ciechanowska-Mendyk K, et al. Ocena skuteczności wybranych zabiegów fizykalnych w leczeniu objawów gonartrozy. Acta Balneologica 2011; 53: 15-21.

10. Szczepański L. Przegląd ocen metod leczenia zachowawczego choroby zwyrodnieniowej stawów. Postępy Nauk Medycznych 2011; 24: 27-33.

11. Jefanow Ol. Wibroakustyka w medycynie. Zbiór prac na temat terapii wibroakustycznej. Vita-Nova, Sankt Petersburg 2002; 15-27.

12. Kurtow Al. Oddziaływanie wibroakustyczne w kompleksowym leczeniu chorych. Materiały dla Lekarzy. Sankt Petersburg 2003.

13. Fiodorow W, Kowelenow A, Loginow G, et al. Zasoby organizmu. Nowe podejście do ustalania etiologii chorób i do metod ich leczenia. Wyd. I. Medsportpress, Warszawa 2013.

14. Robertson V, Word A, Low J, et al. Ultradźwięki. In: Fizykoterapia. Aspekty kliniczne i biofizyczne. Łukowicz M (ed.). Elsevier Urban \& Partner, Wrocław 2006: 259-321.

15. Fedorov V. Vitafon treatment and disease prevention. RTC IMPEX, Moscow 2002; 15-68.

16. Wasiljew AE, Kowielenow AJ, Kowlen DW, et al. Zasoby organizmu - układ odpornościowy, zdrowie, długowieczność. Vita Nova, Sankt-Petersburg 2004.

17. Łukasiak A, Krystosiak M, Widłak P, et al. Ocena skuteczności leczenia pacjentów z tzw. ostrogą piętową z zastosowaniem terapii wibroakustycznej. Doniesienie wstępne. Ortopedia Traumatologia Rehabilitacja 2013; 15: 77-87.

18. Stępień M, Piątkowski P, Rokicki R. Zastosowanie terapii wibroakustycznej u pacjentów po leczeniu operacyjnym choroby Dupuytrena. Fizjoterapia Polska 2012; 12: 355-362.

19. Rankovich B. Influence of vibroacoustic effect of "Vitafon" on ventilation rate and respiration in patients with chronic lung obstructions (COPD). Proceedings of the Fourth International Conference "Vibroacoustic in Medicine". Sankt Petersburg 2006: 86-99. 
20. Petrov SB, Lewkowsky NS, Kurtov Al, et al. Research of the efficiency of vibroacoustic treatment method for the complex therapy in patients with prostate gland hyperplasia. Proceedings of the Fourth International Conference "Vibroacoustic in Medicine". Sankt Petersburg 2006: 71-76.

21. Rodomonowa LA, Nakonechniy DG. Vibroacoustic treatment with "Vitafon" for wrist bone fracture. Proceedings of the Fourth International Conference "Vibroacoustic in Medicine". Sankt Petersburg 2006: 77-79.

22. Skopowska A, Łukowicz M, Szymańska J, et al. Sonoterapia w leczeniu objawów choroby zwyrodnieniowej stawu biodrowego. In: Wybrane aspekty rehabilitacji. Pozowski A, Jarząba S (eds.). Wrocław 2011: 378-385.

23. Speed CA. Therapeutic ultrasound in soft tissue lesions. Rheumatology 2001; 40: 1331-1336.

24. Kurtaiş Gürsel Y, Ulus Y, Bilgiç A, et al. Adding ultrasound in the management of soft tissue disorders of the shoulder: a randomized placebo-controlled trial. Phys Ther 2004; 84: 336-343.

25. Warden SJ, McMeeken JM. Ultrasound usage and dosage in sports physiotherapy. Ultrasound Med Biol 2002; 28: 1075 1080.

26. Czernicki J, Woldańska-Okońska M, Mockałło W, et al. Ocena wyników leczenia fizykalnego chorych ze zmianami zwyrodnieniowymi stawów kolanowych fonoforezą z diklofenakiem. Fizjoterapia 1999; 7: 16-18.

27. Warden SJ, Fuchs RK, Kessler CK, et al. Ultrasound produced by a conventional therapeutic ultrasound unit accelerates fracture repair. Phys Ther 2006; 86: 1118-1127.

28. Kujawa J, Talar J, Gworys P, et al. Ocena skuteczności przeciwbólowej laserowej u chorych z chorobą zwyrodnieniową stawu kolanowego. Ortopedia, Traumatologia, Rehabilitacja 2004; 6: 356-366.

29. Skrzek A, Zagrobelny Z. Wpływ krioterapii na czynność układu ruchu osób z chorobą zwyrodnieniową stawu kolanowego. Fizjoterapia 2000; 8: 20-23. 